\section{Global Proceedings Repository \\ American Research Foundation}

ISSN 2476-017X

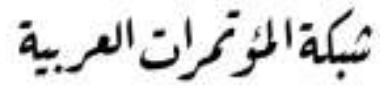

http://arab.kmshare.net/

Available online at http://proceedings.sriweb.org

The Ninth International Scientific Academic Conference

Under the Title "Contemporary trends in social, human, and natural sciences"

$$
\begin{aligned}
& \text { المؤتمر العلمي الاكاديمي الدولي التاسع } \\
& \text { تحت عنوان "الاتحاهات المعاصرة في العلوم الاجتماعية، الانسانية، والطبيعية" } \\
& 17 \text { - } 18 \text { يوليو - تموز } 2018 \text { - اسطنبول - تركيا }
\end{aligned}
$$

http://kmshare.net/isac2018/

\title{
Histopathologic Study in lung \& kidney of mice post Infection with Klebsiellae pneumoniae
}

\author{
Zainab I. Ibrahim ${ }^{\text {a }}$ \\ \& \\ ${ }^{\text {a }}$ Zainab J. M. Jawad \\ ${ }^{\text {a }}$ University of Baghdad/ Al-Jadryia, Baghdad-Iraq \\ zainabalrubaei@yahoo.com \\ zainab0jamal@yahoo.com
}




\section{Global Proceedings Repository \\ American Research Foundation}

ISSN 2476-017X

Available online at http://proceedings.sriweb.org

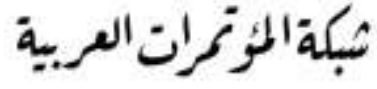

http://arab.kmshare.net/

\begin{abstract}
:
Klebseilla pneumoniae ( $k$. pneumoniae) as opportunistic pathogen caused nosocomial infections 5\%$20 \%$ of cases from gram-negative bacterial sepsis, and multidrug-resistant in clinical cases a serious health. Klebseilla has the ability to disseminate and colonize most internal organs and the inflammation was rapidly converted from acute to chronic stages. K. pneumonia is a frequent cause of severe pneumonia with extensive lung destruction due to neutrophil infiltration (purulent exudate) in the pulmonary tissue, which is the pathologic lesion of bacterial pneumonia. The present experiment concerned on the histopathologic examination of lung and kidney in mice post- infection intraperitoneal with pathogenic local isolate of k.pneumoniae. Fifty Balb /mice as two groups: $1^{\text {st }}$ group $(\mathrm{n}=20)$ infected with $0.5 \mathrm{ml}\left(2 \times 10^{9} \mathrm{CFU} / \mathrm{ml}\right) \mathrm{I} / \mathrm{P}$ and $2^{\text {nd }}$ group $(\mathrm{n}=20)$ re-infected as in $1^{\text {st }}$ group, $3^{\text {rd }}$ group $(\mathrm{n}=10)$ injected I/P with PBS as negative control group. The microscopic lesions of (lung and kidney) post-infection and re-infected were examined. Results: at (4, 8 and 16 hours) the microscopic sections revealed acute inflammatory response, and post 7 days until 14 (re-infection) showed chronic inflammatory response. Conclusions: The roles of pathogenic klebseilla in induction acute infection post few hours which developed to chronic infection post 7 days reinfection.
\end{abstract}

Keywords: Klebsiella pneumoniae, infection, recurrent infection, pathogenesis of klebsiella pneumonia, histopathology, kidney, lung . 


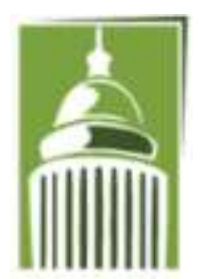

ARF

\section{Global Proceedings Repository \\ American Research Foundation}

ISSN 2476-017X

Available online at http://proceedings.sriweb.org

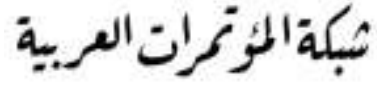

http://arab.kmshare.net/

\section{1-Introduction:}

Klebsiella $s p$. is gram negative bacteria and important opportunistic pathogens causing life-threating nosocomial infections (1). The virulence factors of $K$. pneumonia strains include the capsular serotype, lipopolysaccharide L.P.S (O- Ag), capsular polysaccharide C.P.S (K-Ag), iron scavenging systems, and fimbrial and non-fimbrial adhesins and produce protective against a disease via both humoral and cellmediated immunity $(2 \& 3)$. K. pneumoniae is responsible for a variety of diseases in humans and animals, is a prominent nosocomial pathogen mainly responsible for urinary tract, respiratory tract or blood infections (sepsis) (4), resistce to antibiotics (6) which are related to Biofilm formation in Klebsiella, so scientists have tended to produce vaccines or antigens against $K$. pneumoniae as some researchers in the world (5). WSK Ag was provided a good immune response better than WHKK Ags against infection, also the encapsulated K.pneumoniae has the ability to dissemination and colonization of most internal organs and the inflammation was rapidly convert from acute to chronic stages. Lower respiratory tract infections have always remained a cause of concern for medical care in the world associated with both community acquired and nosocomial pneumonia with high mortality rates of chronic pneumonia in untreated cases (7), even the immunocompetent elderly as well as the healthy non-elderly adults are at a risk of developing pneumonia (8 \&9). Recently, pyogenic liver abscess (PLA) (16) occurs in diabetic patients with a prevalence rate from $45 \%$ to $75 \%$. Sometimes complicated endophthalmitis or meningitis emerged in Taiwan and other Asian countries, and other continents (10 \& 11). Rhinoscleroma and atrophic rhinitis (also called ozaena) are two chronic and potentially severely disturbing diseases of the upper respiratory tract, associated respectively with $K$. pneumoniae subsp (12), meningitis, necrotizing fasciitis and prostatic abscess reported as severe cases (13).

Finally, granuloma inguinale (donovanosis) is caused by uncultivated bacteria, which may belong to $K$. pneumoniae (14).

Endogenous Endophthalmitis (EE) in the USA and Asian population (15). Potential explanations for these geographic differences in clinical manifestations include host factors such as rates of diabetes mellitus, alcoholism, access to healthcare, and socioeconomic factors (17).

\section{2-Materials and Methods:}

2-1:Bacterial isolate: was obtained from Microbiology department Science college, which isolated from a case of urinary tract infection and the bacterial isolate was maintained on brain-heart infusion agar slant then transferred on MacConkey agar $\left(37^{\circ} \mathrm{C} / 24 \mathrm{hrs}\right.$.) to study the morphology of the bacterial colonies and biochemical tests (18 ) gram's stain and capsule stain also.

2-2: Culture media: prepared according to the manufactures company (Oxoid) and sterilized by autoclave in $121^{\circ} \mathrm{C}$ under $15 \mathrm{p} / \mathrm{inj}^{2}$ for 15 minutes; which are:

1- $\quad$ MacConkey agar. 


\section{Global Proceedings Repository \\ American Research Foundation}

ISSN 2476-017X

Available online at http://proceedings.sriweb.org

2- $\quad$ Nutrient agar.

3- Brain-heart infusion broth.

4- Triple sugar iron agar.

5- $\quad$ Simon citrate agar.

6- Indol.

7- $\quad$ Methyl red \& Voges proskauer broth.

8- Urea broth.

2-3: Laboratory animals: were maintained in the animal house of Veterinary Medicine College for two weeks with a good conditions from nutrition and standard environmental conditions from light and temperature.

2-4: Infective dose: the pure culture of bacteria was estimated to prepare the infective dose by serial tenfold dilutions with sterile PBS; it was $2 \times 10^{9} \mathrm{CFU} / \mathrm{ml}$.

2-5:Histopathological examination: according to (19) by using fixative formalin $10 \%$, processing of tissue samples was done automatically, embedded in liquid paraffin and sectioned 4-5 $\mu \mathrm{m}$ and stained manually by Hematoxyline and Eosin stain (H\&E stain) then examined by light microscope on 10X, 20X and 40X magnification.

2-6: Experiment design: Fifty of laboratory mice were divided randomly as following:

First group: $(\mathrm{n}=20)$ infected with $0.5 \mathrm{ml}$ I.P $\left(2 \times 10^{9} \mathrm{CFU} / \mathrm{ml}\right) / 24 \mathrm{hrs}$.

Second group: $(\mathrm{n}=20)$ re- infected with $0.5 \mathrm{ml}$ I.P $\left(2 \times 10^{9} \mathrm{CFU} / \mathrm{ml}\right) / 7-14$ days

Third group: $(\mathrm{n}=10)$ injected with PBS as control group.

At early to 24 hours post infection and at 7-14 days re-infected, sacrificed the then preserved their lung and kidney tissues in $10 \%$ formalin for histopathology preparation.

\section{3-Results:}

\section{3-1: Pathological study:}

3-1-1: Gross appearance: during few hours post- bacterial infection showed congestion (red color) of internal organs (lung and kidneys), edema also in mice re-infected but in less amount of edematous fluid.

3-1-2: Histopathology: the sections of lung and kidney showed severe acute inflammatory changes at few hours post-infection characterized by; congestion of B.Vs (dilated and filled with blood), presence of edematous fluid in interstitial tissues, fibrin and infiltration of PMNs (neutrophils), (Figure: 1) at 16 hours liquifactive necrosis also noted (figure-2) that agreed with (1) who described acute respiratory infection post-intranasal infection and in glomerular tuft as kidney changes (20) after intra-urethral infection. 


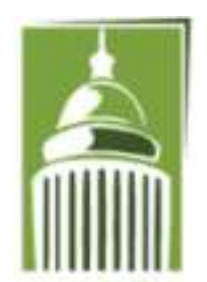

ARF

\section{Global Proceedings Repository \\ American Research Foundation}

ISSN 2476-017X

Available online at http://proceedings.sriweb.org

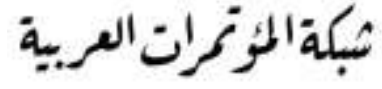

http://arab.kmshare.net/

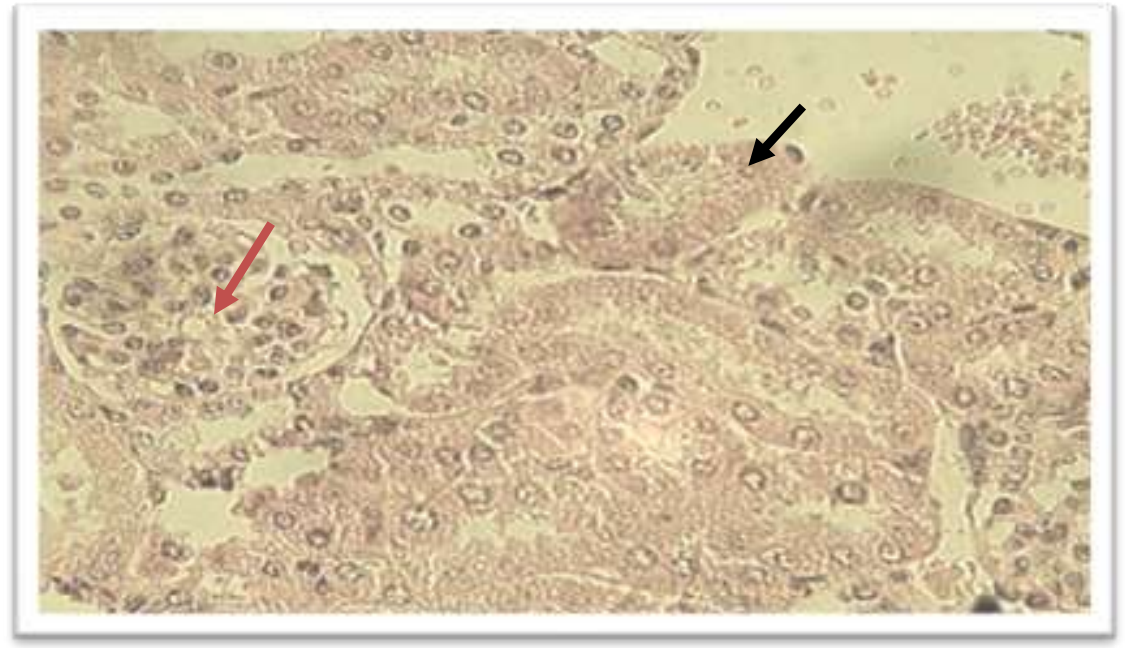

Figure-1: Histopathologic section in kidney of mouse at 8 hours post-infection; showed acute cell swelling of tubularlining epithelia ) congestion of glomerular tuft and vacuolar degeneration of their endothelium ( $)(\mathrm{H} \& \mathrm{E}$ stain, 40X).

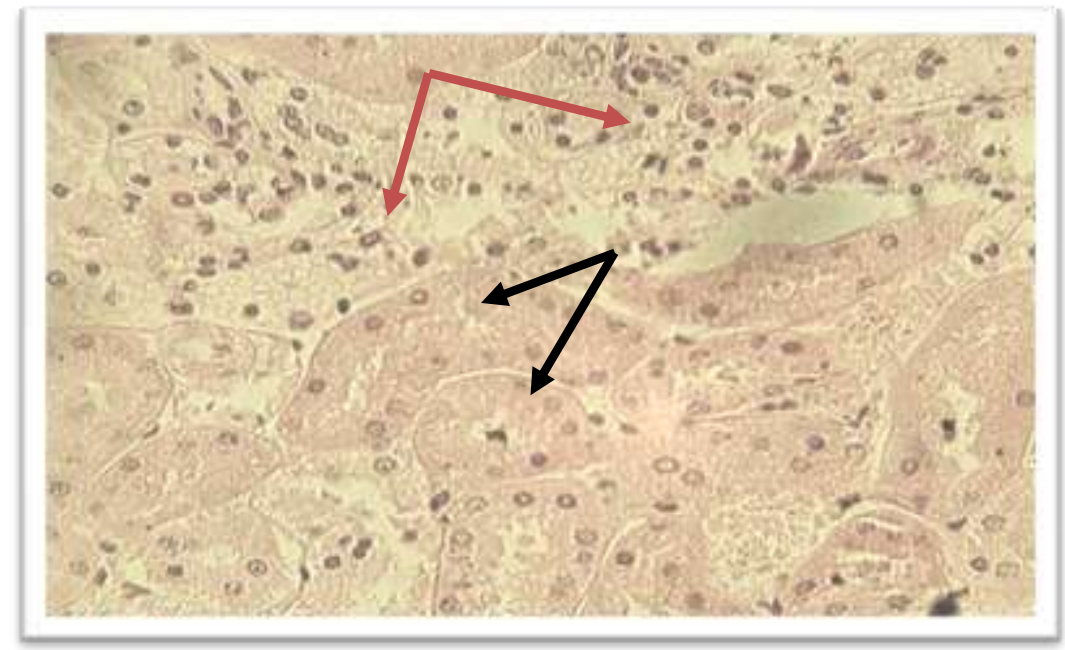

Figure-2: Histopathologic section in kidney of mouse at 16 hours post- infection; revealed prominent epithelial cell swelling (star-shaped $(\longrightarrow$ ) liquifyed necrotic tissue in peritubular and within tubules $(\longrightarrow$. (H\&E stain, 40X). 


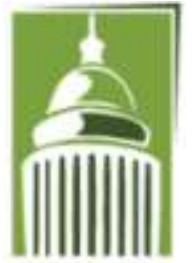

ARF

\section{Global Proceedings Repository American Research Foundation}

ISSN 2476-017X

Available online at http://proceedings.sriweb.org

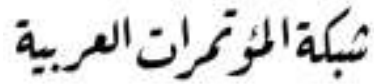

http://arab.kmshare.net/

At 7 - 14 days from re- infection significant histopathologic lesions were less blood vessels congestion and fibrinous exudate with PMNs infiltrated and few lymphocytes also (Figure-3\&4).

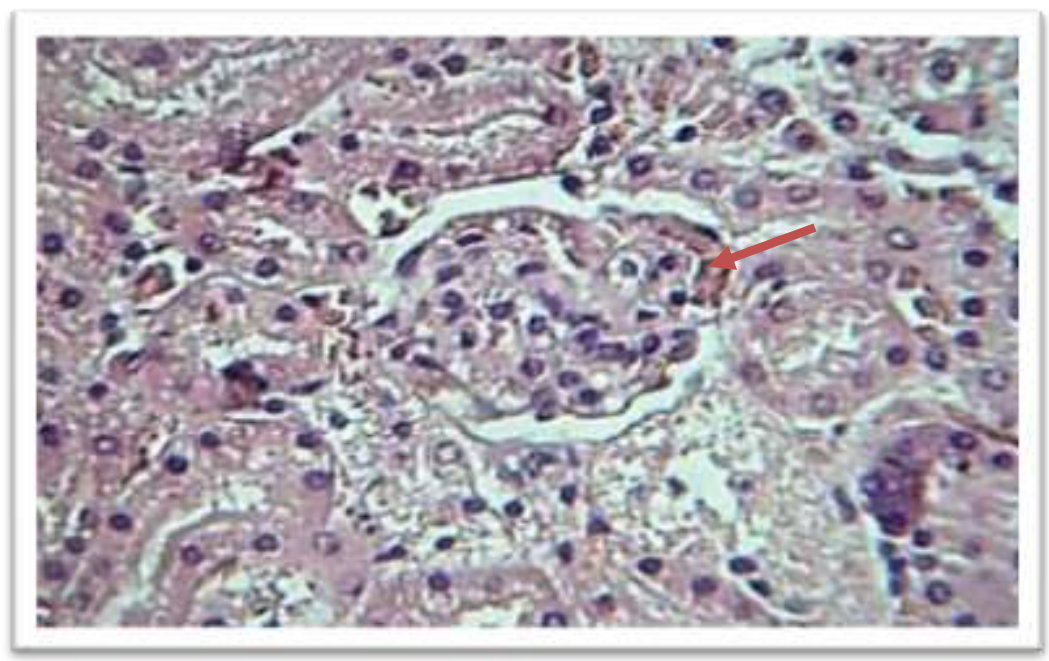

Figure-3: Histopathologic section in kidney of mouse at 7 days re-infection; infiltration of PMNs within glomerular tuft $(<-$ (H\&E, 40X).

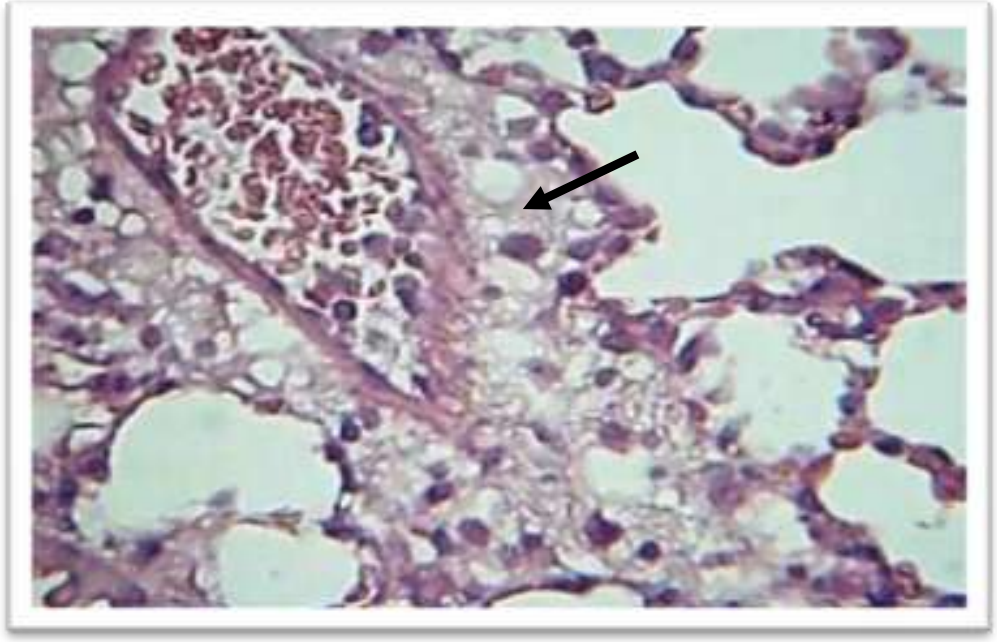

Figure-4: Histopathologic section in lung of mouse at 7 days post- re-infection; showed fibrinous exudate perivascular and in interstitial \& in alveoli $(\longleftarrow)$ (H\&E, 40X). 


\section{Global Proceedings Repository \\ American Research Foundation}

ISSN 2476-017X

Available online at http://proceedings.sriweb.org

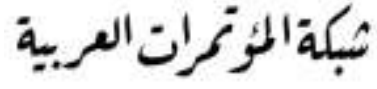

http://arab.kmshare.net/

ARF

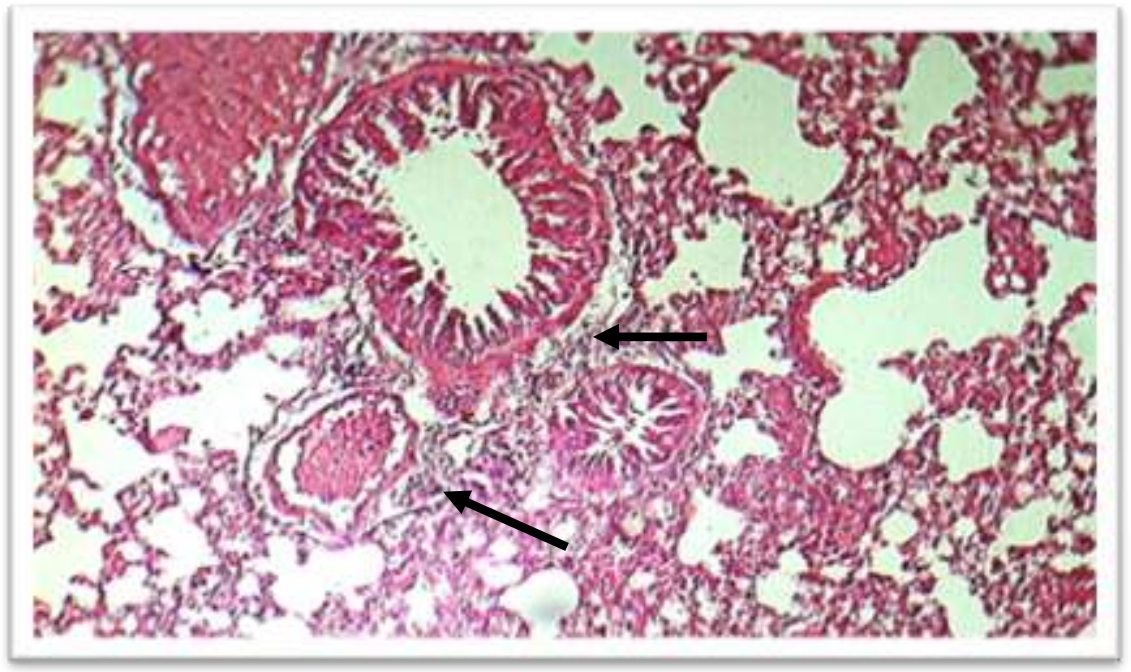

Figure-5: Histopathologic section in lung of mouse at 14 days re-infection; showed lymphocytic peribronchiolitis.

$(\leftarrow)$ (H\&E stain, 10X).

\section{4- Discussion:}

The present study appeared predominant infiltration composed from polymorphonuclear cells (neutrophils) in most sections of lung and kidney organs through few hours post bacterial infection and reinfection. the histopathologic examination of lung tissue illustrate that the infection begins as congestion of blood vessels, edema and few neutrophils infiltration during early hours post infection. At few days later (week and more) the lesion progress to lobar pneumonia, consolidation of pulmonary lobules, (21) who noted that neutrophils as phagocytic cells so are critical to inhibit bacterial growth (22) who noted the chronic infection post exposure to bacterial infection again. On day 14 of infection, revealed chronic pulmonary changes in the lungs of infected mice with positive bacterial load, tissue damage (necrosis) of alveoli.

The experiments deals that the central mechanism of Klebsiella pathogenesis is the production of a LPS-rich cell surface protected germ cells against immune response (23). That evident in the present study from occurrence of bacterial infection in early time and sustained days later in re-infected mice.

However, (24) who explain that non-immunized animals may indicated a wide spectrum of severe pathological lesions post infection which upheld by (25) who demonstrated that $K$. pneumoniae was accompanied with massive pathological changes such as suppurative infections in lung, liver, urinary tract and brain, disseminated all over the world. Neutrophilic cells mainly in examined organs may indicated $K$. pneumoniae infection activated the cytokines production IL-6, IL-8, TNF- $\alpha$ and IL- $1 \beta$ which have prime role in inflammatory cells attraction $(\mathbf{2 6}, \mathbf{2 7})$ revealed that the Enterobacteriaceae bacteria showed proliferation of mononuclear cells aggregation around congested veins and other blood vessels which also contained the inflammatory cells in their lumen. 


\section{Global Proceedings Repository \\ American Research Foundation}

ISSN 2476-017X

Available online at http://proceedings.sriweb.org

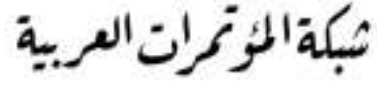

http://arab.kmshare.net/

ARF

\section{Conclusions:}

1- The capacity of klebsiella pneumoniae to induce infection due to had virulence pathologic agent in acute inflammatory changes post few hours intraperitoneal infection.

2-The lesions characterized by PMNs infiltration, edema admixed with fibrinous exudate later in the Lung and kidney tissues.

\section{References:}

1- Sharma, S; Chhibber, S; Mohan, H. and Sharma, H. (2012). Induction of Chronic Pneumonia in Normal Mice by Klebsiella pneumoniae Am. J. Biomed. Sci., 4(2):102-110.

2- Chou, H.C; Lee, C.Z; Ma, L.C; Fang, C.T; Chang, S.C; et al. (2004) Isolation of a chromosomal region of Klebsiella pneumoniae associated with allantoin metabolism and liver infection. Infect Immun, 72: 3783-3792.

3- Eickoff, T.C; Steinhauer, B.W; Finland, M. (1966) .The Klebsiella-Enterobacter-Serratia division. Biochemical and serological characteristitcs and susceptibility to antibiotics. Annales of Internal Medicine, 65: 1163-1179.

4- Podschun, R. and Ullmann, U. (1998). Klebsiella spp. as nosocomial pathogens: epidemiology, taxonomy, typing methods, and pathogenicity factors. Clin Microbiol Re, 11: 589-603.

5- Unkel, B; Hoegner, K; Clausen, B.E; Lewe-Schlosser, P; Bodner, J; Gattenloehner, S; Janssen, H; Seeger, W; Lohmeyer ,J; Herold, S. (2012). Alveolar epithelial cells orchestrate DC function in murine viral pneumonia. J Clin Invest, 122:3652-3664.

6- Woodford, N; Reddy, S; Fagan, E.J;, Hill, R.L; Hopkins, K.L; et al. (2007). Wide geographic spread of diverse acquired AmpC beta-lactamases among Escherichia coli and Klebsiella spp. in the UK and Ireland. J Antimicrob Chemother, 59:102-105.

7- Angeles-Garav, U; Chavez, Y.V; Flores, A.V.E; Martinez, J.C. and Guerrero, M.E.L. (2005). Nosocomial infections in a high speciality hospital. Factors associated to mortality in infected patient. Rev. Med. Inst. Mex. Seguro. Soc. 43: 381-391.

8- Marrie, T.J. (2000). Community- acquired pneumonia in elderly. Clin. Infect. Dis. 31: 1066 1078.

9- Fang, C.T; Lai, S.Y; Yi, W.C; Hsueh, P.R; Liu, K.L; et al. (2007) Klebsiella pneumonia genotype K1: an emerging pathogen that causes septic ocular or central nervous system complications from pyogenic liver abscess. Clin Infect Dis, 45: 284-293.

10- Rahimian, J; Wilson, T; Oram, V; Holzman, R.S. (2004) .Pyogenic liver abscess: recent trends in etiology and mortality. Clin Infect Dis, 39: 1654-1659.

11- Hart, C.A. and Rao, S.K. (2000). Rhinoscleroma. J Med Microbiol, 49: 395-396. 


\section{Global Proceedings Repository \\ American Research Foundation}

ISSN 2476-017X

Available online at http://proceedings.sriweb.org

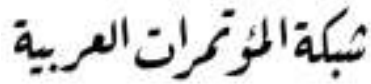

http://arab.kmshare.net/

ARF

12- Wong, C. H., Kurup, A., Wang, Y. S., Heng, K. S. \& Tan, K. C. (2004).Four cases of necrotizing fasciitis caused by Klebsiella species. Eur. J.Clin. Microbiol Infect. Dis. 23, 403-407.

13- Kabha, K; Schmegner, J; Keisari, Y; Parolis, H; Schlepper-Schaeffer, J. \& Ofek, I. (1997). SP-A enhances phagocytosis of Klebsiella by interaction with capsular polysaccharides and alveolar macrophages. Am J Physiol. 272: L344-52.

14- Kashani,A. H. and Eliott, D. (2013). The emergence of Klebsiella pneumoniae endogenous endophthalmitis in the USA: basic and clinical advances. Journal of Ophthalmic Inflammation and Infection, 3:28.

15- Al-Mahmood, A.M; Al-Binali, G.Y; Alkatan, H; Abboud, E.B; Abu El-Asrar, A.M. (2011). Endogenous endophthalmitis associated with liver abscess caused by Klebsiella pneumoniae. Int Ophthalmol 31(2):145-148.

16- Ko, W.C; Paterson, D.L; Sagnimeni, A.J; Hansen, D.S; Von Gottberg, A; Mohapatra, S, et al. (2002). Community-acquired Klebsiella pneumoniae bacteremia: global differences in clinical patterns. Emerg Infect Dis. 8:160-166.

17- Cowan, S.T. (1974). Cowan \& Steel's, Manual for the identification of medical bacteria. $2^{\text {nd }}$ ed. Cambridge University press, PP: 106.

18- Finegold, S.M. and Martin, W.J. (1982). Diagnostic Microbiology. $6^{\text {th }}$ Ed. The C.V. Mosby Company, PP: 199.

19- Godkar, P.B. and Godkar, D.P. (2003).Textbook of Medical Laboratory Technology.2ed, Bhalani Publishing House, Mumbai, India.pp:1002

20- Ibrahim, Z.I.(1998). Infection of Klebsiella pneumonia in urinary tract of female rats and guinea pigs. MSc. in pathology. College of Veterinary Medicine, University of Baghdad.

21- Ahmad, T.A; EL-Sayed L.H; Haroun M, Hussein A.A; Al Ashry E.S.H. (2012). Development of immunization trials against Klebsiella pneumoniae. Vaccine, 30:2411-2420.

22- Mittal, R., Kaur, A., Joshi, K., Nada, R., Chhibber, S., Harjai, K. and Sharma, S. (2009). Experimental non- obstructive chronic renal infection model with planktonic and biofilm cells of Pseudomonas aeruginosa. Am. J. Biomed. Sci. 1(2): 103-114.

23- Matthew, S; Lawlor, J. H; Paul, D; Rick and Virginia, L. M. (2005). Identification of Klebsiella pneumoniae Virulence determinants using an intranasal infection model. Molecular Microbiology 58(4): 1054-1073.

24- Al-Lamy, S. A. T. and Zghair, Z. R. (2017). Comparative study of Klebsiella pneumoniae in mice immunized with two types of antigens. Journal of Entomology and Zoology Studies.5(6): 470-475.

25- Abdullah, S.H.M. \& Zghair, R. (2016). Isolation of Klebsiella pneumoniae from urine of human and cattle in Baghdad city with histopathological study experimentally in mice. International Journal of Advanced Research in Biological Sciences. 3(10):38-45.

26- Mansour, A.M.A; Zaki, H.M; Hassan, N.A. \& Al-Humiany, A.A. (2014). Molecular characterization and immunoprotective activity of Capsular Polysaccharide of Klebsiella pneumoniae isolated from farm animals at Taif Governorate. American Journal of Infectious Diseases. 10(1):1-14. 


\section{Global Proceedings Repository \\ American Research Foundation}

ISSN 2476-017X

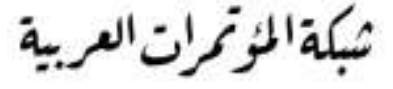

http://arab.kmshare.net/

ARF

Available online at http://proceedings.sriweb.org

27- Lundberg, U; Senn, B.M; Schuler, W; Meinke, A. \& Hanner, M. (2013). Identification and characterization of antigens as vaccine candidates against Klebsiella pneumonia. Human Vaccines \& Immunotherapeutics journal. 9(3):497-505. 